\title{
Targeting Bax interaction sites reveals that only homo-oligomerization sites are essential for its activation
}

\author{
R Peng ${ }^{1,2,3}$, J-S Tong ${ }^{2,3}, \mathrm{H} \mathrm{Li}^{2,3}, \mathrm{~B}$ Yue ${ }^{1}, \mathrm{~F} \mathrm{Zou}^{\star, 1}, \mathrm{~J} \mathrm{Yu}^{2,4}$ and L Zhang ${ }^{\star, 2,3}$
}

Bax is a proapoptotic $\mathrm{Bcl}-2$ family member that has a central role in the initiation of mitochondria-dependent apoptosis. However, the mechanism of Bax activation during apoptosis remains unsettled. It is believed that the activation of Bax is mediated by either dissociation from prosurvival Bcl-2 family members, or direct association with BH3-only members. Several interaction sites on Bax that mediate its interactions with other Bcl-2 family members, as well as its proapoptotic activity, have been identified in previous studies by other groups. To rigorously investigate the functional role of these interaction sites, we knocked in their respective mutants using HCT116 colon cancer cells, in which apoptosis induced by several stimuli is strictly Baxdependent. Bax-mediated apoptosis was intact upon knock-in (KI) of K21E and D33A, which were shown to block the interaction of Bax with BH3-only activators. Apoptosis was partially reduced by $\mathrm{KI}$ of D68R, which impairs the interaction of Bax with prosurvival members, and S184V, a constitutively mitochondria-targeting mutant. In contrast, apoptosis was largely suppressed by KI of L70A/D71A, which blocks homo-oligomerization of Bax and its binding to prosurvival Bcl-2 family proteins. Collectively, our results suggest that the activation of endogenous Bax in HCT116 cells is dependent on its homo-oligomerization sites, but not those previously shown to interact with BH3-only activators or prosurvival proteins only. We therefore postulate that critical interaction sites yet to be identified, or mechanisms other than protein-protein interactions, need to be pursued to delineate the mechanism of Bax activation during apoptosis.

Cell Death and Differentiation (2013) 20, 744-754; doi:10.1038/cdd.2013.4; published online 8 February 2013

Stress-induced apoptosis in mammalian cells is governed by the Bcl-2 family, ${ }^{1-5}$ which includes prosurvival members, such as $\mathrm{Bcl}-2, \mathrm{Bcl}-\mathrm{X}_{\mathrm{L}}, \mathrm{Mcl}-1$ and $\mathrm{Bcl}-\mathrm{w}$, proapoptotic members Bax and Bak, and proapoptotic BH3-only proteins, such as Bim, Bid, Bad, PUMA and Noxa. ${ }^{3}$ Among these proteins, Bax has a central role in apoptosis initiation. ${ }^{6}$ It is ubiquitously expressed and often exists as inactive monomers in the cytoplasm. ${ }^{7}$ Upon activation by $\mathrm{BH} 3-$ only proteins, Bax undergoes a conformational change and translocates to mitochondria where it multimerizes, leading to mitochondrial outer membrane permeabilization, release of mitochondrial apoptogenic proteins, such as cytochrome $c$, and activation of caspases. ${ }^{8}$ The mechanism of Bax activation, regarded as 'the holy grail of apoptosis research', ${ }^{4}$ has remained unsettled. Two models have been proposed to explain Bax activation. ${ }^{9}$ In the indirect model, Bax is bound and sequestered by prosurvival Bcl-2 proteins. ${ }^{3,10}$ During apoptosis, BH3-only proteins bind to prosurvival Bcl-2 proteins to relieve their inhibition of Bax. ${ }^{11}$ In the direct model, several BH3-only activators, such as truncated Bid (tBid), Bim and perhaps PUMA, directly bind to Bax and induce its conformational change. Other BH3-only members activate Bax by binding to prosurvival proteins to release BH3-only activators. ${ }^{12-14}$

Delineating the mechanism of Bax activation has relied on studies of critical residues in its functional domains. The $\mathrm{BH} 3$ domain of Bax mediates its association with other Bcl-2 family proteins and homo-oligomerization. Several $\mathrm{BH} 3$ residues of Bax, including D68, L70 and D71, have been shown to mediate its interactions with prosurvival Bcl-2 proteins. ${ }^{15-17}$ The first $\alpha$ helix $(\alpha 1)$ of Bax stabilizes its conformation and inhibits its homo-oligomerization in healthy cells. ${ }^{12,18} \mathrm{BH} 3-$ only activators such as tBid and PUMA can directly bind to the $\alpha 1$ helix of Bax to expose its $\mathrm{N}$ - and $\mathrm{C}$-termini, which results in its mitochondrial targeting and homo-oligomerization. ${ }^{12,18}$ Critical $\alpha 1$ residues for Bax activation include D33, which is responsible for its interactions with tBid and PUMA, ${ }^{13,18}$ and $\mathrm{K} 21$, which is in contact with the $\mathrm{BH} 3$ domain of Bim. ${ }^{19}$ Mutations in these sites abrogated the interaction of Bax with

\footnotetext{
${ }^{1}$ College of Life Sciences, Sichuan University, Chengdu, Sichuan, China; ${ }^{2}$ University of Pittsburgh Cancer Institute, University of Pittsburgh School of Medicine, Pittsburgh, PA, USA; ${ }^{3}$ Department of Pharmacology and Chemical Biology, University of Pittsburgh School of Medicine, Pittsburgh, PA, USA and ${ }^{4}$ Department of Pathology, University of Pittsburgh School of Medicine, Pittsburgh, PA, USA

${ }^{*}$ Corresponding author: L Zhang, UPCI Research Pavilion, Hillman Cancer Center, 5117 Centre Ave, Room 2.42a, Pittsburgh, PA 15213, USA. Tel: 4126231009. Fax: 4126237778.

E-mail: zhanglx@upmc.edu

or F Zou, College of Life Sciences, Sichuan University, Chengdu, Sichuan, 610064, China. Tel: +8628 85412805. Fax: +862885414886.

E-mail: fundzou@yahoo.com.cn

Keywords: Bax; apoptosis; mitochondria; Bcl-2 family; caspases

Abbreviations: BH, Bcl-2 homology; CHAPS, 3-[(3-Cholamidopropyl)-dimethylammonio]-1-propane sulfonate; Cox IV, cytochrome oxidase subunit IV; DSP, dithiobis (succinimidyl) propionate; GFP, green fluorescent protein; HA, hemaglutinin; IP, immunoprecipitation; KO, knockout; KI, knock-in; MEF, mouse embryonic fibroblast; NP40, Nonidet P-40; NSAID, non-steroidal anti-inflammatory drug; PI, propidium iodide; TNF, tumor necrosis factor; TRAIL, tumor necrosis factor-related apoptosis inducing ligand; tBid, truncated Bid

Received 10.04.12; revised 30.12.12; accepted 07.01.13; Edited by C Borner; published online 08.2.13
} 
Table 1 Bax interaction site mutants analyzed

\begin{tabular}{|c|c|c|}
\hline Bax mutant & Phenotype & Reference \\
\hline K21E & $\begin{array}{l}\text { Impaired Bax interaction with stapled } \\
\text { Bim BH3 peptide }\end{array}$ & 19 \\
\hline D33A & $\begin{array}{l}\text { Impaired Bax interaction with the } \mathrm{BH} 3 \\
\text { domains of Bid and PUMA }\end{array}$ & 13,18 \\
\hline D68R & $\begin{array}{l}\text { Impaired Bax interaction with } \mathrm{Bcl}-2 \text {, } \\
\mathrm{Bcl}-\mathrm{X}_{\mathrm{L}}, \mathrm{Bcl}-\mathrm{w} \text { and } \mathrm{Mcl}-1\end{array}$ & 16 \\
\hline L70A/D71A & $\begin{array}{l}\text { Abrogated Bax interaction with } \mathrm{Bcl}-\mathrm{X}_{\mathrm{L}} \\
\text { and } \mathrm{Mcl}-1\end{array}$ & 17 \\
\hline S184V & $\begin{array}{l}\text { Constitutively targeting Bax to } \\
\text { mitochondria }\end{array}$ & 12 \\
\hline
\end{tabular}

BH3-only activators, and impaired its activation and Baxdependent apoptosis. ${ }^{12,13,17,18}$ However, it has been difficult to detect direct interactions between Bax and $\mathrm{BH} 3-$ only activators. ${ }^{11,20}$ Studies of Bax activation have mostly utilized artificial systems, such as peptides, in vitro translated proteins, cell-free assays and exogenous Bax reconstitution. Results from these studies are confusing and hard to reconcile with each other.

To gain insight into the mechanism of Bax activation, we knocked-in several previously described Bax interaction site mutants using $B A X$-knockout $(B A X-\mathrm{KO})$ HCT116 colon cancer cells, which exhibit clear-cut Bax-dependent apoptotic phenotypes in response to several stimuli, and have been widely used in apoptosis research. ${ }^{21-23}$ Comparing the activities of different mutants reveals that only the homooligomerization sites are required for Bax activation.

\section{Results}

Knock-in (KI) of the Bax interaction site mutants in HCT116 cells. Five Bax interaction site mutants were selected for gene targeting based on their respective phenotypes described in previous studies (Table 1). These mutants were knocked into $B A X-\mathrm{KO} \mathrm{HCT} 116$ cells, which contain two non-functional $B A X$ alleles, including the $\mathrm{KO}$ allele, and a mutant allele caused by a single base pair deletion in the G8 tract (nucleotide 114-121) of $B A X$ that results in a frame-shift deletion. ${ }^{21}$ Targeting constructs were designed specifically for the mutant allele to introduce WT or mutant $B A X$ coding sequences, and correct the frame-shift deletion (Figures $1 \mathrm{a}$ and $\mathrm{b}$ ). As a control for gene targeting, WT $B A X$ was also knocked into $B A X-K O$ cells (Figure 1a). Sequencing of both $B A X$ genomic DNA and cDNA verified correct gene targeting events in each of the $\mathrm{KI}$ cell lines (Supplementary Figures S1A-F). WT and mutant Bax in the $\mathrm{KI}$ cells were found to be expressed at similar levels relative to that of endogenous Bax in the parental HCT116 cells (Figure 1c).

Previous studies showed that $B A X-\mathrm{KO}$ HCT116 cells are completely resistant to apoptosis induced by sulindac, ${ }^{21}$ a non-steroidal anti-inflammatory drug (NSAID) used for cancer chemoprevention, ${ }^{24}$ and that induced by tumor necrosis factor (TNF)-related apoptosis inducing ligand (TRAIL), a TNF family death receptor ligand that can induce apoptosis through a crosstalk between the extrinsic and intrinsic pathways. ${ }^{22,23}$ To determine the functional consequences of Bax mutations,

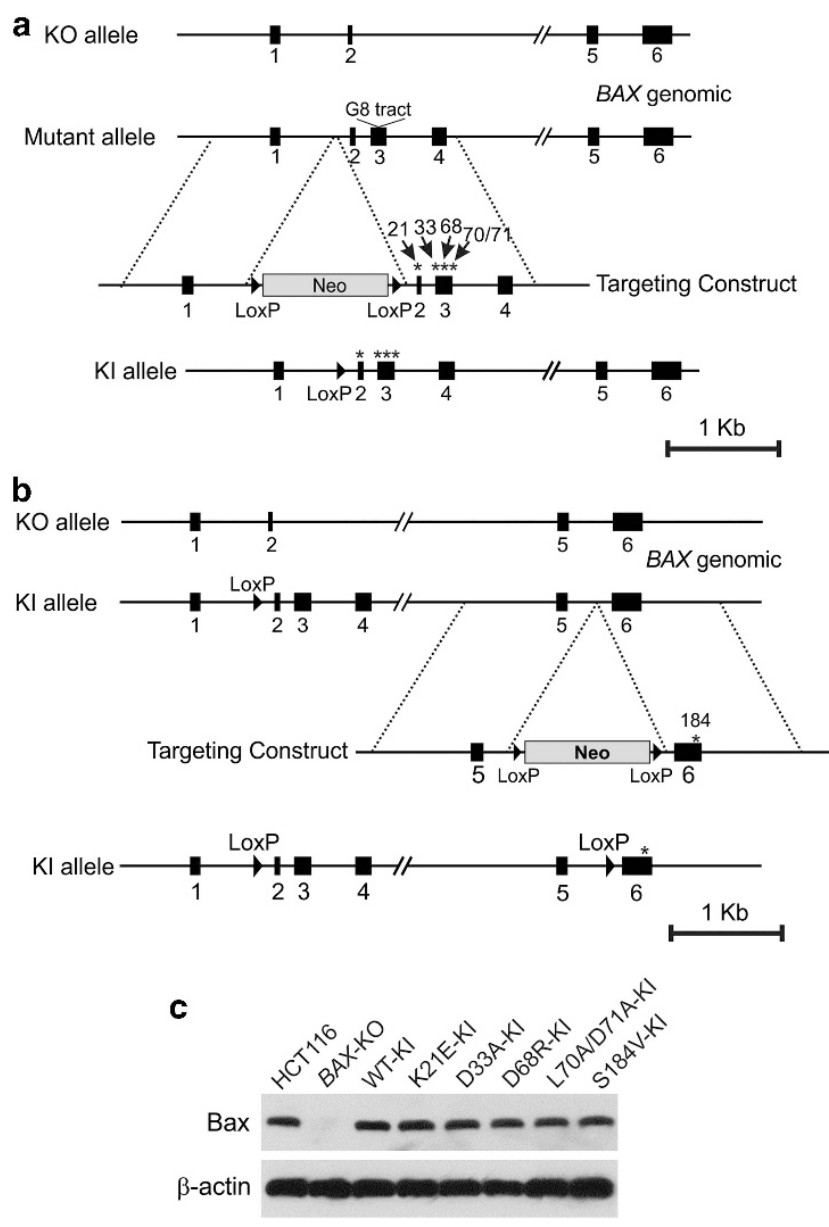

Figure $1 \mathrm{KI}$ of Bax mutants. (a) Schematic representation of $B A X$ genomic locus in BAX-KO HCT116 cells and the targeting constructs for knocking-in WT, K21E, D33A, D68R and L70A/D71A. (b) Schematic representation of BAX genomic locus of WT-KI cells and the targeting construct for knocking-in the S184V mutant. (c) The expression of WT and mutant Bax in the indicated KI cell lines was analyzed by western blotting. WT and BAX-KO HCT116 cells were used as control

cells with different $B A X$ genotypes were treated with sulindac and TRAIL. As expected, KI of WT Bax (WT-KI) fully restored sulindac- and TRAIL-induced apoptosis analyzed by nuclear staining (Figures $2 \mathrm{a}$ and $\mathrm{b}$ ), or annexin $\mathrm{V}$ staining (Supplementary Figure S2). Bax undergoes a conformational change to promote mitochondrial outer membrane permeabilization and cytochrome $c$ release. ${ }^{5}$ Sulindac and TRAIL induced similar levels of Bax conformational change and cytochrome $c$ release in WT-KI and parental HCT116 cells (Figures $3 a-d)$. Therefore, Bax in the WT-KI cells is as functional as that in the parental HCT116 cells. Sulindac, but not TRAIL, was also found to induce expression of multiple BH3-only proteins, including Bim, PUMA and Bad (Supplementary Figure S3A).

Targeting interaction sites for BH3-only activators did not inhibit Bax-dependent apoptosis. Mutation of K21E in the Bax $\alpha 1$ helix disrupts its interaction with a stapled Bim $\mathrm{BH} 3$ peptide. ${ }^{19}$ However, we were unable to detect by immunoprecipitation (IP) any interaction between endogenous or transfected Bax and Bim in HCT116 cells (Figure 4a 

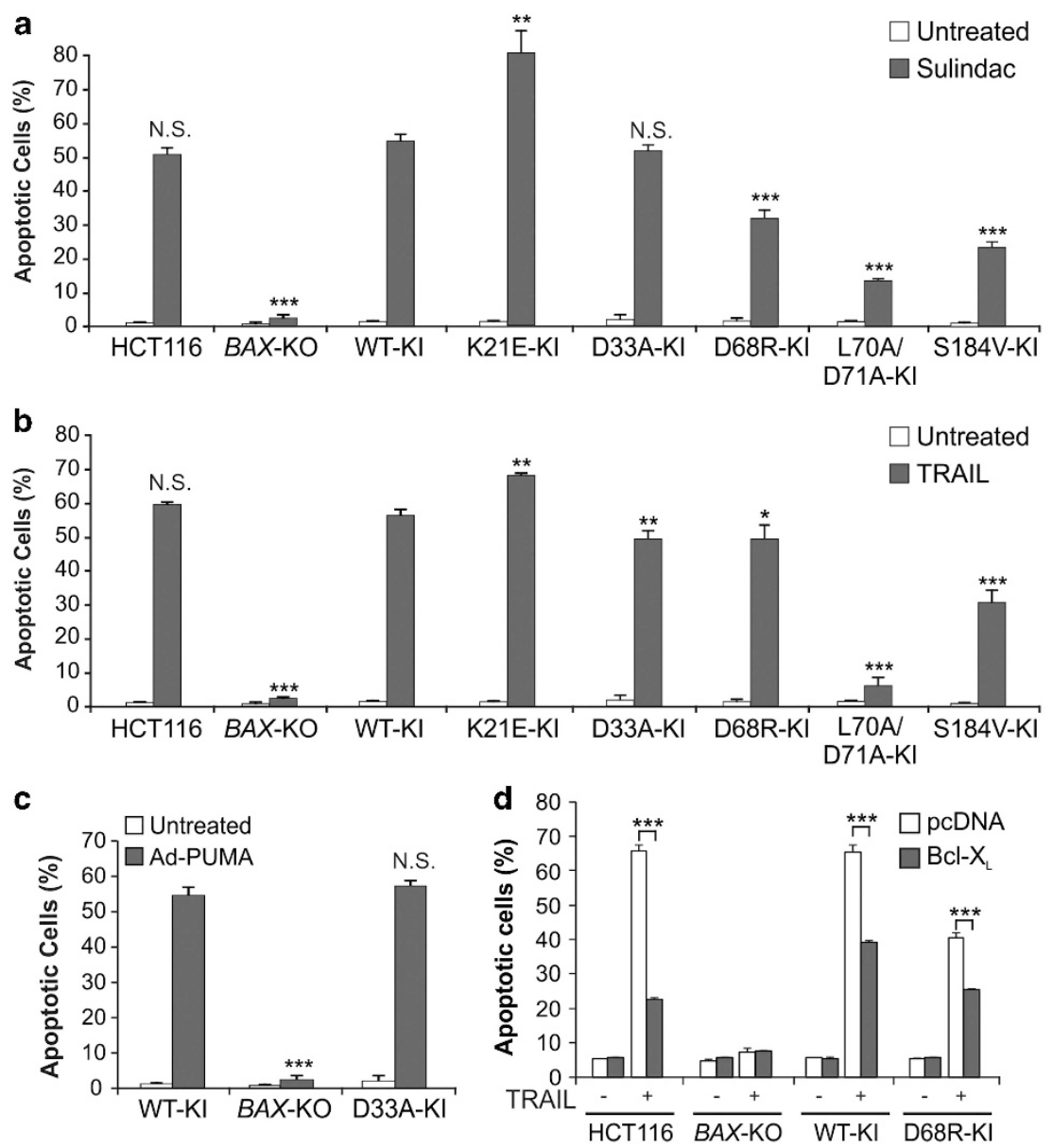

Figure 2 Apoptosis in HCT116 cells with different BAX status. (a) Parental, BAX-KO, WT-KI, K21E-KI, D33A-KI, D68R-KI, L70A/D71A-KI and S184V-KI HCT116 cells were treated with $120 \mu \mathrm{m}$ sulindac for $48 \mathrm{~h}$. Apoptosis was measured by nuclear fragmentation assay after nuclear staining with Hoechst 33258 . Statistical analysis was performed by comparing WT-KI and other cell lines. (b) HCT116 cells with indicated BAX genotypes were treated with $10 \mathrm{ng} / \mathrm{ml}$ TRAIL for $24 \mathrm{~h}$. Apoptosis was analyzed as in (a). (c) Parental, BAX-KO and D33A-KI HCT116 cells were infected with a PUMA-expressing adenovirus for $48 \mathrm{~h}^{32}$ Apoptosis was determined as in (a). (d) Parental and indicated KI HCT116 cells were transfected with V5-tagged Bcl- $\mathrm{X}_{\mathrm{L}}$, and then treated with TRAIL as in (b). Apoptosis was determined as in (a). N.S.: not statistically significant; ${ }^{*} P<0.05 ;{ }^{* *} P<0.01 ;{ }^{* *} P<0.001$

and data not shown), which express Bim that is functional upstream of Bax under certain conditions. ${ }^{25}$ This is probably due to weak or transient interaction between these two proteins in HCT116 cells. The previous study also showed that the K21E mutant has reduced ability to promote staurosporine-induced apoptosis in mouse embryonic fibroblast (MEF) cells compared with WT Bax. ${ }^{19}$ Surprisingly, we found that apoptosis induced by sulindac and TRAIL was not reduced, but slightly enhanced in K21E-KI cells, in comparison to WT-KI or parental HCT116 cells (Figures 2a and b). This difference in apoptosis was confirmed by annexin $\mathrm{V}$ staining (Supplementary Figure S2). Similar to WT Bax, the K21E mutant was capable of undergoing conformational change and inducing cytochrome $c$ release (Figures $3 a-d)$, in response to sulindac or TRAIL treatment. These results clearly indicate that the $\mathrm{K} 21$ residue of $\mathrm{Bax}$ is not necessary for Bax activation in HCT116 cells.

D33, also a residue in the $\alpha 1$ helix of Bax, was shown to directly interact with PUMA and tBid, and the D33A mutant failed to coprecipitate with tBid in glioblastoma cells. ${ }^{13,18} \mathrm{We}$ were unable to detect any interaction between PUMA and Bax in WT-KI or parental HCT116 cells (data not shown). To confirm the reported activity of D33A, BAX-KO cells were cotransfected with HA-tagged PUMA and GFP-tagged WT Bax or D33A mutant, and analyzed by IP for the interaction between PUMA and Bax. Still no interaction could be detected between PUMA and GFP-tagged WT or mutant Bax (Figure $4 \mathrm{~b}$ upper panel). The lack of association of PUMA or Bim with Bax was confirmed in cells lysed with different detergents, including Nonidet P-40 (NP-40) and 3-[(3-Cholamidopropyl)-dimethylammonio]-1-propane sulfonate (CHAPS) (Supplementary Figure S4). In contrast, WT Bax could bind to tBid, but the D33A mutant disrupted this interaction, upon transfection of V5-tagged tBid into WT-KI or D33A-KI HCT116 cells (Figure $4 b$, lower panel).

To determine whether the direct interaction between Bax and PUMA or tBid is critical for its apoptosis induction, WT-KI and D33A-KI HCT116 cells were compared for apoptosis induced by sulindac, TRAIL, or PUMA overexpression. D33A$\mathrm{KI}$ cells were as sensitive as WT-KI cells to apoptosis induced by sulindac or TRAIL (Figures 2a and b; Supplementary Figure S2), or by PUMA overexpression (Figure 2c). Similar to WT 
a

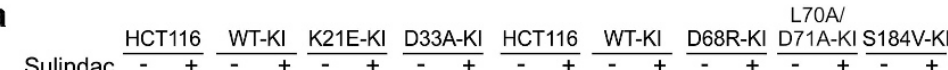

IB: Bax N20 - - - - I IP: Bax 6A7

b
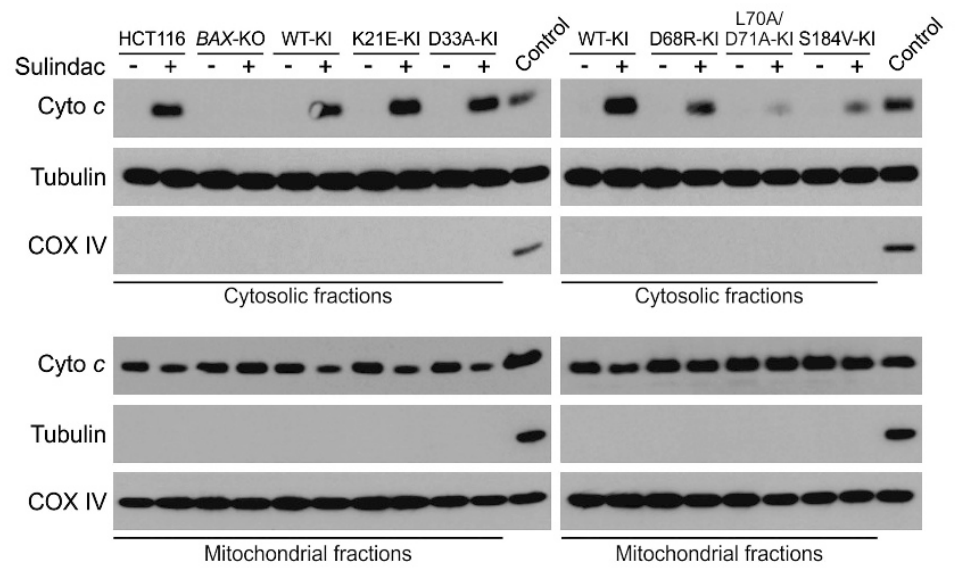

C

TRAIL $\frac{\text { HCT116 }}{-+} \frac{\text { WT-KI }}{-+} \frac{\text { K21E-KI }}{-+} \frac{\text { D33A-KI }}{-+} \frac{\text { HCT116 }}{-+} \frac{\text { WT-KI }}{-+} \frac{\text { D68R-KI }}{-} \frac{\text { D710A }-K I}{-} \frac{\text { S184V-KI }}{-}+$

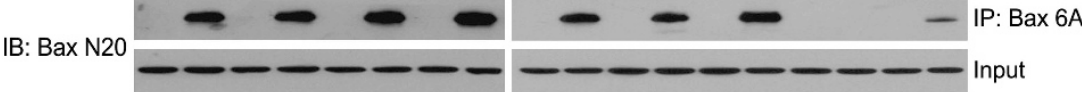

d
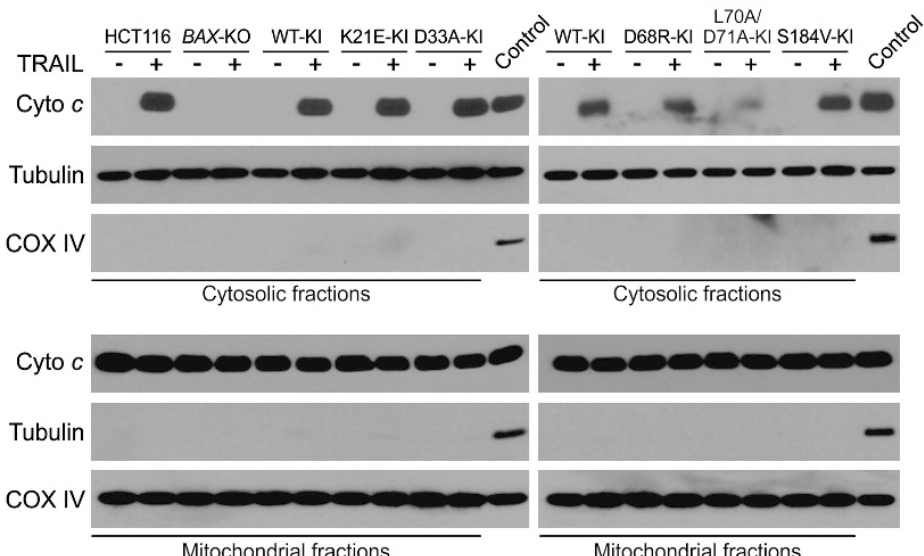

Figure 3 Comparison of WT Bax and different mutants for their ability to undergo conformational change and induce cytochrome $c$ release. (a) HCT116 cells with indicated $B A X$ genotypes were treated with $120 \mu \mathrm{m}$ sulindac for $36 \mathrm{~h}$. Cells were lysed in CHAPS lysis buffer and probed for Bax conformational change by IP with anti-Bax 6 A7 antibody, followed by western blotting using N20 anti-Bax antibody. (b) Cytosolic and mitochondrial fractions were isolated from cells treated as in (a) and probed for cytochrome $c$ by western blotting. Cytochrome oxidase subunit IV (Cox IV) and tubulin, which are exclusively expressed in mitochondria and cytoplasm, respectively, were used as control for loading and fractionation. (c) HCT116 cells with indicated BAX genotypes were treated with $10 \mathrm{ng} / \mathrm{ml}$ TRAIL for $24 \mathrm{~h}$ and analyzed for Bax conformational change as in (a). (d) Cytosolic and mitochondrial fractions were isolated from cells treated with TRAIL as in (c) and probed for cytochrome $c$ by western blotting. 'Control' in (b) and (d) corresponds to HCT116 whole-cell lysate

Bax, the D33A mutant underwent conformational change and triggered cytochrome $c$ release in response to sulindac and TRAIL treatment (Figures 3a-d). Therefore, if Bax residue D33 mediates an interaction with PUMA or tBid, such an interaction seems to be dispensable for Bax-mediated apoptosis.

Targeting the interaction site for prosurvival proteins partially inhibited Bax-dependent apoptosis. The D68R mutant of Bax was previously shown to disrupt its interaction with prosurvival $\mathrm{Bcl}-2$ proteins, including $\mathrm{Bcl}-2, \mathrm{Bcl}-\mathrm{X}_{\mathrm{L}}, \mathrm{Bcl}-\mathrm{w}$ and $\mathrm{Mcl}-1 .{ }^{16}$ Indeed, the D68R mutant failed to coprecipitate with Bcl-2, Bcl- $\mathrm{X}_{\mathrm{L}}, \mathrm{Bcl}-\mathrm{w}$ and $\mathrm{Mcl}-1$ in HCT116 cells (Figure $4 \mathrm{c}$ ). Contrary to the notion that prosurvival $\mathrm{Bcl}-2$ proteins bind to Bax to prevent its activation, apoptosis induced by sulindac and TRAIL was not enhanced, but slightly reduced in $\mathrm{D} 68 \mathrm{R}-\mathrm{KI}$ cells, relative to WT-KI cells (Figures 2a and b; Supplementary Figure S2). Although the D68R mutant cannot be bound by the prosurvival $\mathrm{Bcl}-2$ proteins, it remained inactive without any treatment, but became activated upon sulindac or TRAIL exposure 
a

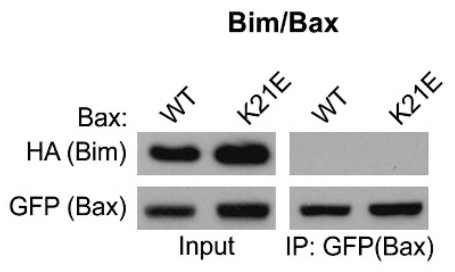

C

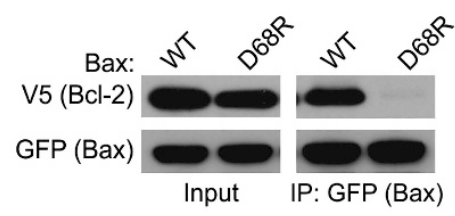

Bcl-X/Bax

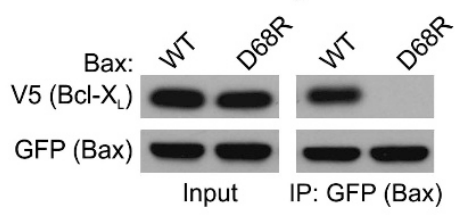

d

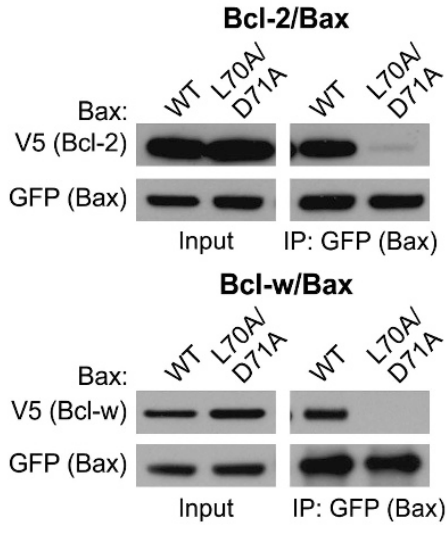

b

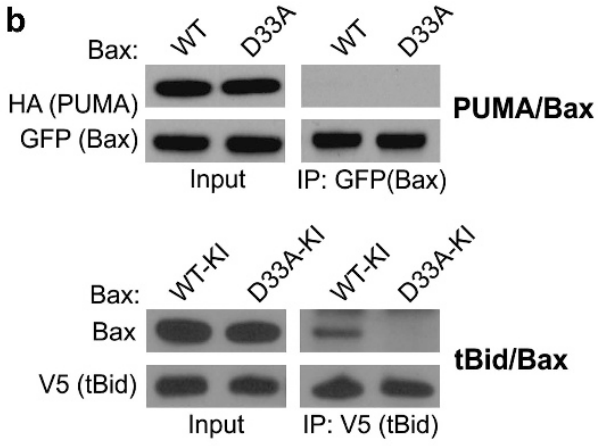

Bcl-w/Bax

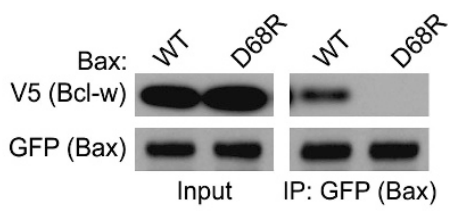

Mcl-1/Bax
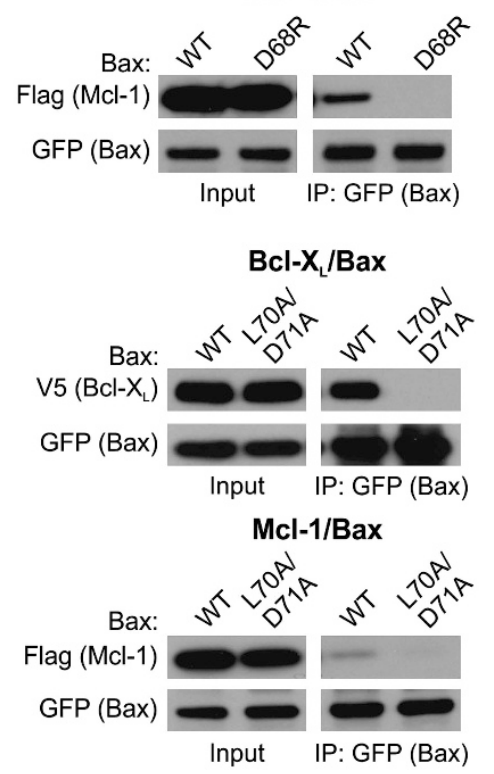

Figure 4 Interactions of WT and mutant Bax with other Bcl-2 family members. BAX-KO HCT116 cells were cotransfected with GFP-tagged WT or mutant Bax, along with HA-, V5- or Flag-tagged another Bcl-2 family member. IP was performed with anti-GFP antibody to pull down Bax, followed by western blot analysis of the interaction of Bax with the cotransfected protein in the IP complexes. For analysis of tBid and Bax interaction, WT and D33A-KI cells were transfected with V5-tagged tBid and anti-V5 antibody was used for IP. (a) Interaction between GFP-tagged WT or K21E mutant Bax with HA-tagged Bim. (b) Upper, Interaction between GFP-tagged WT or D33A mutant Bax with HA-tagged PUMA; Lower, Interaction between V5-tagged tBid and WT Bax in WT-KI cells, or mutant Bax in D33A-KI cells. (c) Interaction between GFP-tagged WT or D68R mutant Bax with V5-tagged Bcl-2, Bcl-w, Bcl-X or Flag-tagged Mcl-1. (d) Interaction between GFP-tagged WT or L70A/D71A mutant Bax with V5-tagged Bcl-2, Bcl-w, Bcl-X, or Flag-tagged Mcl-1

(Figures 3a and c). D68R was also able to promote TRAILand sulindac-induced cytochrome $c$ release (Figures $3 b$ and d). Furthermore, transfection of $\mathrm{Bcl}-\mathrm{X}_{\mathrm{L}}$, a critical survival factor in HCT116 cells, ${ }^{26}$ similarly suppressed Bax-dependent apoptosis in the parental, WT-KI, and D68R-KI HCT116 cells (Figure 2d and Supplementary Figure S5). These results suggest that the ability of prosurvival $\mathrm{Bcl}-2$ proteins to inhibit Bax-dependent apoptosis does not require their direct interaction with Bax, which was also indicated previously. ${ }^{16}$ Therefore, although it was shown that Bax is bound and inhibited by prosurvival proteins in healthy HCT116 cells, ${ }^{20}$ the release of Bax from Bcl-2 proteins alone seems to be insufficient for Bax activation, which may require additional signals conferred by upstream BH3-only activators.

Targeting Bax homo-oligomerization abolished Bax-dependent apoptosis. The L70A/D71A mutant of Bax is unable to bind to the prosurvival $\mathrm{Bcl}-2$ family members $\mathrm{BCl}-\mathrm{X}_{\mathrm{L}}$ and $\mathrm{Mcl}-1$ in MEF cells, and can be selectively activated by $\mathrm{BH} 3-$ only proteins in response to certain stimuli. ${ }^{17}$ We confirmed that 
a
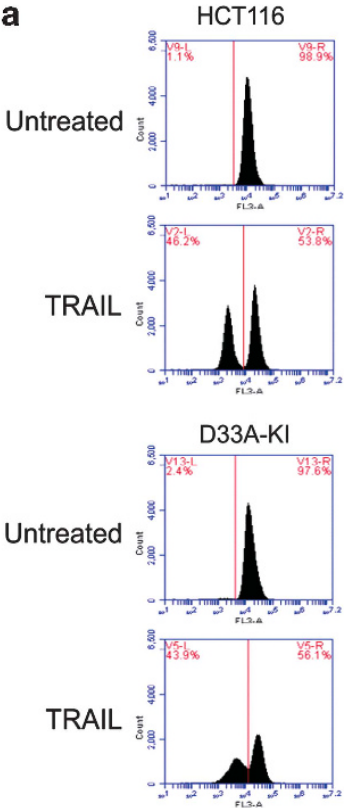
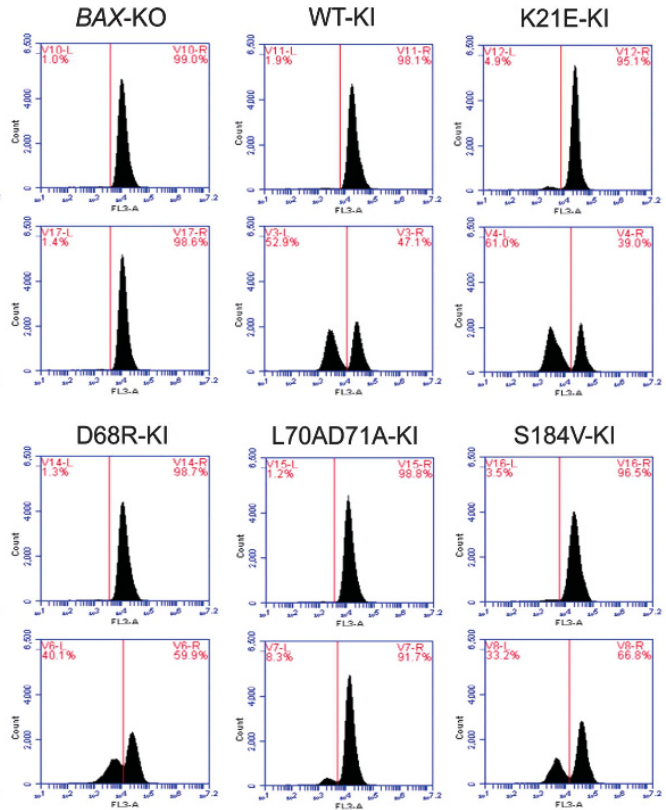

b

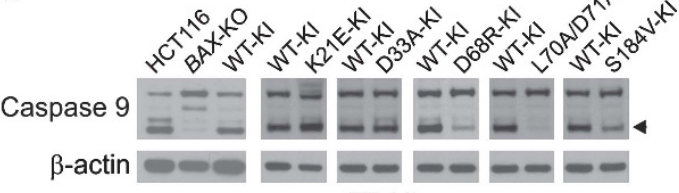

TRAIL

d
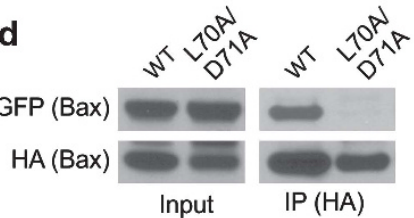

IP (HA) c

Sulindac
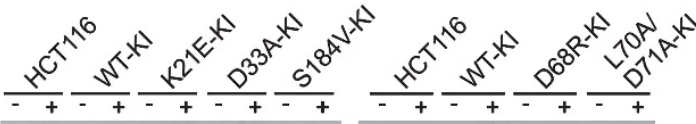

Bax

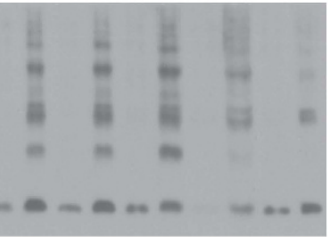

Cox IV

$\beta$-actin

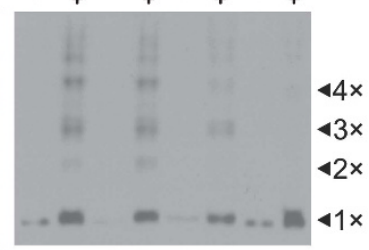

-

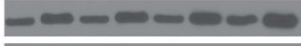

Figure $5 \mathrm{~L} 70 \mathrm{~A} / \mathrm{D} 71 \mathrm{~A}$, but not other Bax mutants, loses the ability to multimerize, interact with each other, and induce mitochondrial membrane potential change and caspase activation. (a) HCT116 cells with indicated $B A X$ genotypes were treated with $10 \mathrm{ng} / \mathrm{ml}$ TRAlL for $24 \mathrm{~h}$. Mitochondrial membrane potential was analyzed by staining cells with MitoTrcker Red CMXRos, followed by flow cytometry. (b) Cells with indicated BAX genotypes were treated with TRAIL as in (a). Activation of caspase 9 was analyzed by western blotting. Arrowheads indicate active caspase 9. (c) Mitochondrial fractions were isolated from cells with different $B A X$ genotypes treated with $120 \mu \mathrm{m}$ sulindac for $36 \mathrm{~h}$. Bax multimerization was analyzed by treating mitochondrial fractions with the chemical cross-linker DSP, followed by western blotting under non-denaturing conditions. Cox IV and $\beta$-actin were used as control for loading and fractionation. (d) BAX-KO cells were cotransfected with HA-tagged and GFP-tagged WT Bax or HA-tagged and GFPtagged L70A/D71A mutant. IP was performed to analyze the interaction of Bax with each other

the transfected L70A/D71A mutant could not interact with Bcl- $X_{L}$, Mcl-1 and Bcl-w, but could weakly bind to Bcl-2 (Figure 4d). Apoptosis induced by sulindac and TRAIL was markedly reduced in L70A/D71A-KI cells, compared with WT-KI cells (Figures 2a and b; Supplementary Figure S2). The L70A/D71A$\mathrm{KI}$ cells were also resistant to indomethacin, another NSAID that can induce Bax-dependent apoptosis, ${ }^{21}$ compared with WT-KI cells (Supplementary Figure S6). In response to TRAIL and sulindac treatment, the L70A/D71A mutant failed to undergo conformational change (Figures $3 \mathrm{a}$ and $\mathrm{c}$ ), or promote substantial cytochrome $c$ release (Figures $3 b$ and $d$ ).

In line with apoptosis induction, Bax-dependent mitochondrial membrane permeabilization was detected in WT and various mutant $\mathrm{KI}$ cells, except for L70A/D71A-KI cells (Figure 5a). Bax-mediated caspase 9 activation, a hallmark of mitochondria-mediated apoptosis, ${ }^{2}$ was also detected in WT and mutant $\mathrm{KI}$ cells, but not in L70A/D71A-KI cells
(Figure 5b). L70 and D71 are both located in the BH3 domain of Bax, which mediates its homo-oligomerization and interactions with prosurvival $\mathrm{Bcl}-2$ proteins. We therefore suspected that loss of Bax homo-multimerization may be responsible for apoptotic deficiency in L70A/D71A-KI cells. Among the isogenic cell lines analyzed, only L70A/D71A-KI cells were found to be deficient in Bax homo-oligomerization in response to sulindac treatment (Figure $5 \mathrm{c}$ ). D68R-KI cells had slightly reduced Bax oligomerization, compared with parental and WT-KI cells (Figure 5c), consistent with reduced apoptosis in these cells (Figures $2 a$ and $b$ ). Furthermore, unlike WT Bax, HA- and GFP-tagged L70A/D71A mutant could not be coprecipitated with each other (Figure $5 d$ ). Together, these results suggest that deficiency in Bax-dependent apoptosis in L70A/D71A-KI cells is due to lack of its homo-oligomerization, rather than abrogation of its interactions with prosurvival $\mathrm{Bcl}-2$ proteins. 
a
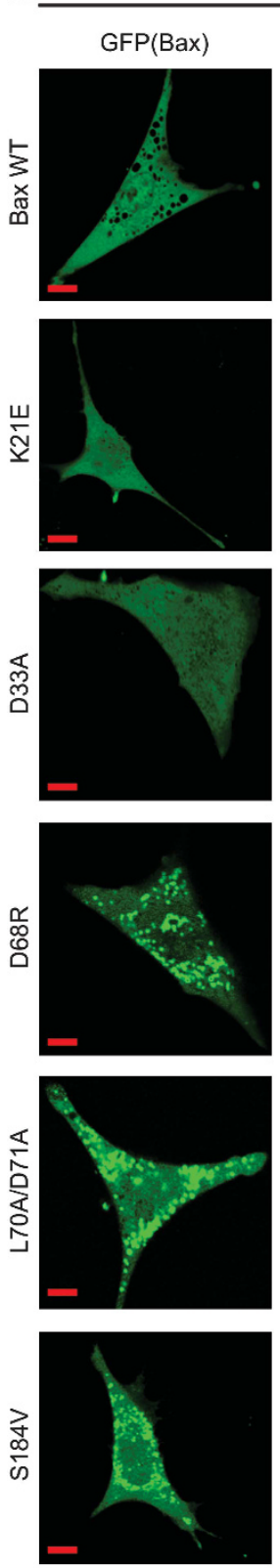

MEF
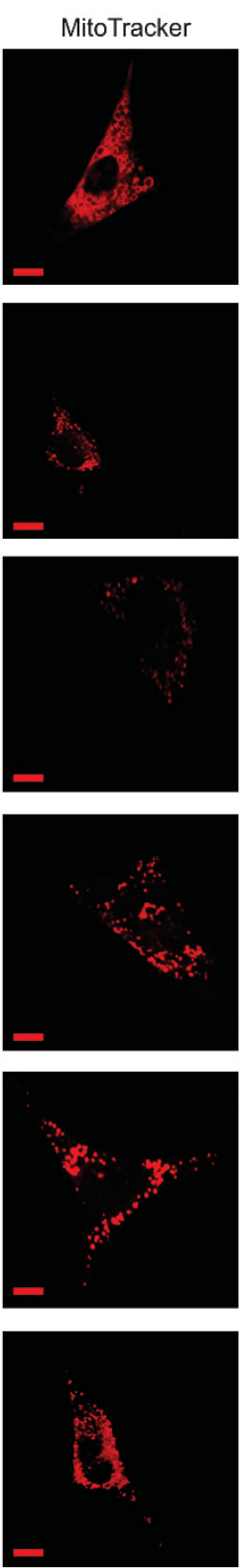
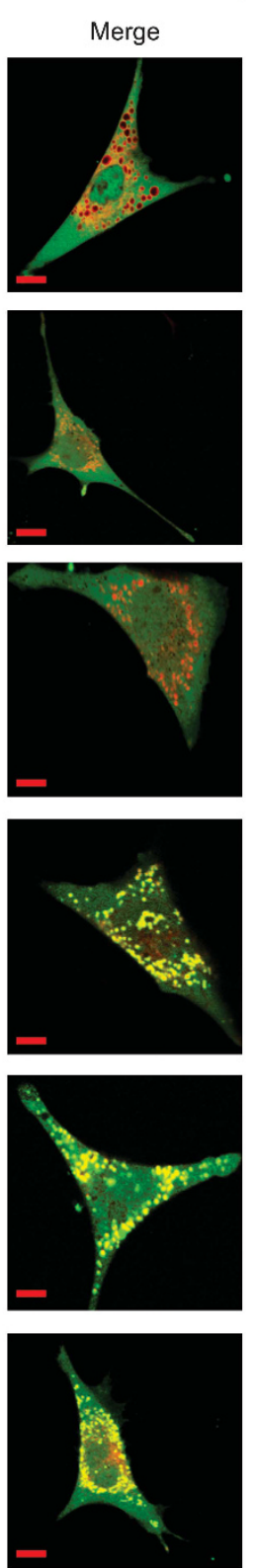

b
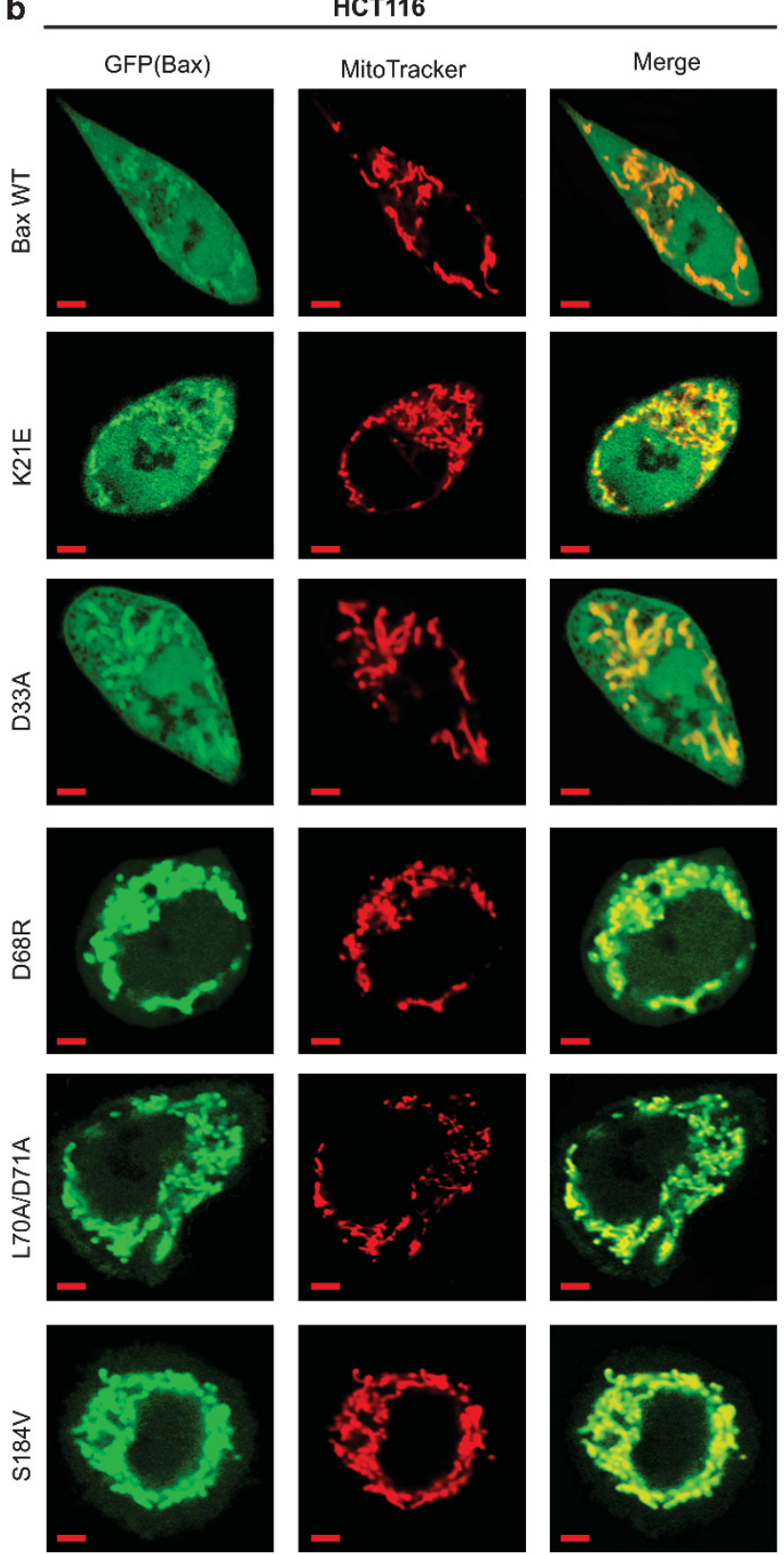

C

\section{$\underline{\text { HCT116 }}$ MEF}

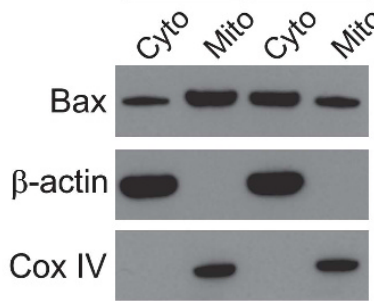

Figure 6 Comparison of subcellular localization of WT and mutant Bax in HCT116 and MEF cells. (a) WT Bax or indicated mutants were transfected into MEF cells Localization of transfected Bax was indicated by GFP fluorescence (green). Mitochondria were stained by MitoTracker Red (red). Scale bars: $5 \mu \mathrm{m}$. (b) WT Bax or indicated mutants were transfected into BAX-KO HCT116 cells, and then analyzed as in (a) for Bax localization. Scale bars: $5 \mu \mathrm{m}$. (c) Cytosolic (Cyto) and mitochondrial (Mito) fractions isolated from healthy HCT116 and MEF cells were normalized and then probed for Bax by western blotting. Cox IV and $\beta$-actin were used as control for loading and fractionation 
Mitochondria-targeting mutant reduced Bax-dependent apoptosis. Bax can translocate from cytoplasm to mitochondria and form homo-oligomers, which promote mitochondrial outer membrane permeabilization following apoptosis induction. We found that transfected WT Bax is distributed in the cytoplasm and mitochondria of both MEF and HCT116 cells (Figures $6 \mathrm{a}-\mathrm{c}$ ), and expressed at similar level relative to endogenous Bax in these cells (Supplementary Figure S3B). However, both transfected and endogenous $\mathrm{Bax}$ is more abundant in the mitochondria of HCT116 cells compared with MEF cells (Figures 6a-c). The S184V mutant of Bax was shown to constitutively target Bax to the mitochondria of MEF cells. ${ }^{12,27}$ We confirmed the mitochondria-targeting of S184V in both MEF and HCT116 cells (Figures $6 \mathrm{a}$ and b). In addition to S184V, D68R and L70A/ $\mathrm{D} 71 \mathrm{~A}$, but not K21E and D33A, were also found to be enriched in the mitochondria of MEF and HCT116 cells (Figures $6 \mathrm{a}$ and b). In addition, Bak is mostly localized in the mitochondria of HCT116 cells, and its expression is unchanged after sulindac and TRAIL treatment (Supplementary Figure S3C).

Consistent with the previous study using MEF cells, ${ }^{12}$ S184V-KI cells did not undergo spontaneous apoptosis without any treatment (Figures $2 \mathrm{a}$ and $\mathrm{b}$ ). However, sulindacand TRAIL-induced apoptosis was substantially reduced in S184V-KI cells, relative to WT-KI cells (Figures 2a and b; Supplementary Figure S2). Despite of the weaker ability to induce apoptosis and caspase activation (Figure 5b), the S184V mutant could still undergo conformational change (Figures $3 a$ and $\mathrm{c}$ ), and promote cytochrome $c$ release (Figures $3 b$ and $d$ ), in response to sulindac and TRAIL treatment. These observations suggest that the S184V mutation may affect other apoptotic functions of Bax in addition to mitochondrial targeting.

\section{Discussion}

Although Bax has a central role in apoptosis, the mechanism of its activation has remained controversial. The direct activation model postulates that the $\mathrm{BH} 3$-only activators, including tBid, Bim and perhaps PUMA, directly bind to and activate Bax and Bak. ${ }^{12,17,28}$ The indirect model suggests that $\mathrm{BH} 3-o n l y$ proteins bind to and neutralize prosurvival $\mathrm{Bcl}-$ 2 proteins, which relieves inhibition of Bax. ${ }^{11,16}$ Both models are supported by multiple lines of evidence, but fail to provide good explanations for several puzzling observations. ${ }^{3,9,10}$ The direct model cannot reconcile why Bax can promote apoptosis even without discernible interaction with the $\mathrm{BH}$ only activators, ${ }^{11}$ while the indirect model does not well explain why Bax activation requires a significant conformational change, ${ }^{10}$ and why Bax mutants that cannot bind to prosurvival Bcl-2 proteins are kept inactive in healthy cells (Figure 3). ${ }^{16}$ Several recent studies suggest that certain aspects of both direct and indirect models may apply to activation of Bax. It was shown that Bcl-2-like proteins sequester BH3-only proteins (MODE 1 inhibition) or Bax/Bak (MODE 2 inhibition) to block apoptosis. ${ }^{9} \mathrm{BH}$-only activators such as tBid sequentially suppress MODE 1 and then MODE 2 inhibition to activate Bax/Bak in stressed cells. Sequestration of Bax/Bak by Bcl-2-like proteins (MODE 2) seems to occur in the mitochondrial membrane, which prevents Bax conformational change detectable by the $6 \mathrm{~A} 7$ antibody. ${ }^{9} \mathrm{~A}$ so-called 'embedded together' model also postulates that it is at intracellular membranes where antiapoptotic Bcl-2 proteins act as dominant-negative regulators of Bax/Bak by binding to the $\mathrm{BH} 3$-only activators and Bax/Bak. ${ }^{29}$ Furthermore, a unified Bax/Bak activation model was proposed to explain a previously described transient Bak activation step. ${ }^{30,31}$ These models seem to provide better explanations for Bax/Bak activation by incorporating features of both direct and indirect models, including quenching of Bax/Bak by binding to $\mathrm{Bcl}-2$-like proteins, direct activation of Bax/Bak by BH3-only activators, and auto-activation of Bax/Bak through oligomerization. ${ }^{9,31}$

Previous studies have described interactions between the $\alpha 1$ helix of Bax and the $\mathrm{BH} 3$ domains of Bim, tBid and PUMA demonstrated using peptides or in vitro translated proteins. ${ }^{12,14,18}$ Mutations in the $\alpha 1$ helix of Bax, such as K21E and D33A, disrupt its interactions with $\mathrm{BH} 3-$ only activators, and suppress Bax-dependent apoptotic activity. ${ }^{12,13,18,19}$ These interactions are thought to be transient and a 'hit-andrun' type, ${ }^{12}$ as it has been difficult to detect an interaction between endogenous Bax and $\mathrm{BH} 3$-only activators. We and others have not been able to detect any interaction of Bax with Bim and PUMA, which are expressed and functional in HCT116 cells. ${ }^{25,32}$ Previous studies on Bax mutants often relied on reconstituting exogenous Bax in Bax- and/or Bakdeficient MEF cells, which may not completely recapitulate actions of endogenous proteins due to responsive cellular changes caused by transfection. Analysis of Bax-mediated apoptosis in MEF cells is also complicated by the redundant function of Bak. ${ }^{33}$ We have used a genetic approach by knocking-in Bax mutants in HCT116 cells, in which apoptosis induced by several stimuli is strictly Bax-dependent. Therefore, activities of Bax mutants can be analyzed without interference of endogenous WT proteins. Using this approach, we found that both $\mathrm{K} 21 \mathrm{E}-\mathrm{KI}$ and D33A-KI cells are as sensitive to Bax-dependent apoptosis as the parental and WT-KI HCT116 cells (Figures $2 a$ and b), suggesting that the interactions between Bax and $\mathrm{BH}$-only activators are not critical for the apoptotic function of Bax in this cell type. Slightly enhanced apoptosis in K21E-KI and D33A-KI cells may be due to partial unfolding of Bax induced by the mutations. ${ }^{13,18,19}$ It remains possible that the transient interactions between Bax and $\mathrm{BH} 3$-only activators that are critical for Bax activation are mediated by other interaction sites yet to be identified. It is also conceivable that other proteins are involved in the activation of Bax by BH3-only activators. Apoptosis induction in HCT116 cells is influenced by the genetic background and elevated expression of prosurvival proteins such as $\mathrm{Bcl}-\mathrm{X}_{\mathrm{L}}$ in this cell line. ${ }^{20} \mathrm{~A}$ recent study showed that the predominant requirement of Bax for apoptosis in HCT116 cells is due to inhibition of Bak by $\mathrm{Mcl}-1{ }^{34}$ Although Bak is largely dispensable for apoptosis in HCT116 cells, ${ }^{34}$ activated Bak may sequester prosurvival proteins (MODE2 inhibition), which may complicate analysis of Bax in HCT116 cells. We were unable to directly compare HCT116 and MEF cells, because MEF cells were insensitive to sulindac and TRAIL, and did not undergo apoptosis and the same mitochondria changes in response to these stimuli 
(data not shown). Our results from HCT116 cells remain to be verified using MEF cells and more physiological systems by a similar $\mathrm{KI}$ approach.

Consistent with previous studies, ${ }^{16,17}$ the D68 and L70/D71 sites are both critical for Bax interactions with prosurvival Bcl-2 proteins (Figures 4c and d). D68R-KI and L70A/D71A-KI cells did not undergo spontaneous apoptosis, and were not more sensitive to apoptosis induction than WT-KI cells. Therefore, restrain of Bax activity by prosurvival $\mathrm{Bcl}-2$ proteins does not seem to require their direct interactions, which was also indicated by previous studies. ${ }^{16,17}$ However, several discrepancies were noted between our observations on these mutants and those made in MEF cells. Bcl- $\mathrm{X}_{\mathrm{L}}$ transfection partially inhibited apoptosis mediated by D68R in HCT116 cells (Figure $2 \mathrm{~d}$ ), but completely blocked apoptosis induced by D68R in $\mathrm{Bcl}-\mathrm{X}_{\mathrm{L}}$-deficient MEF cells. ${ }^{16}$ This discrepancy is likely due to difference in $\mathrm{Bcl}-\mathrm{X}_{\mathrm{L}}$ status in the cells analyzed in these studies. Among the Bax mutants we analyzed using HCT116 cells, only L70A/D71A loses much of the killing activity (Figure 2), as well as the ability to undergo conformational change and multimerize (Figures $3 \mathrm{a}$ and $5 \mathrm{c}$ ), suggesting that Bax conformational change and homo-oligomerization are indispensable for its activation. In contrast, the activity of L70A/D71A in MEF cells was almost intact in staurosporine-induced apoptosis, but largely reduced in etoposide-induced apoptosis, compared with WT Bax. ${ }^{17}$ Bax conformational change could occur in MEF cells even without its activation. ${ }^{12}$ Furthermore, L70A and D71A as individual mutants were fully active in Cos-7 cells, and could undergo conformational change, oligomerization and mitochondrial translocation to promote apoptosis. ${ }^{35}$ These discrepancies may be explained by selective activation of L70A/ $\mathrm{D} 71 \mathrm{~A}$ by different $\mathrm{BH} 3-$ only proteins in response to different apoptotic stimuli. ${ }^{17}$ It was suggested that L70A/D71A is selectively activated in Bim-mediated apoptosis in MEF cells. ${ }^{17}$ In our study, sulindac-induced Bax activation was associated with induction of multiple $\mathrm{BH} 3-$ only proteins, including Bim, PUMA and Bad (Supplementary Figure S3A). tBid was shown to function upstream of Bax in mediating TRAIL-induced apoptosis in HCT116 cells. ${ }^{36}$ Identifying how the $\mathrm{BH} 3-$ only proteins signal through the L70 and D71 sites of Bax during apoptosis may provide an important clue on the Bax activation mechanism.

Bax is distributed in the mitochondria and cytoplasm of healthy HCT116 and MEF cells (Figures 6a and b). However, it is more abundant in the mitochondria of HCT116 cells compared with MEF cells (Figure 6c). Similar to PUMA-mediated apoptosis, ${ }^{32}$ sulindac-induced apoptosis in HCT116 cells also involves translocation of cytoplasmic Bax into mitochondria (Figure $5 \mathrm{c}$ ), which may reflect auto-activation of Bax subsequent to its conformational change in the mitochondria as previously suggested. 9,29,31 The S184V mutant constitutively targets Bax to mitochondria in HCT116 and MEF cells (Figures 6a and b). ${ }^{12}$ Surprisingly, S184V-KI cells were less sensitive to Baxdependent apoptosis (Figures $2 a$ and $b$ ), suggesting that this mutant may affect Bax functions that are independent of mitochondrial targeting. Mutants that are more specific in mitochondrial targeting may need to be analyzed in order to pinpoint how mitochondrial translocation of Bax contributes to its activation.
In conclusion, our data suggest that, activation of Bax does not require sites that were previously shown to mediate its direct interactions with $\mathrm{BH} 3-$ only activators and its release from prosurvival proteins per se. Therefore, we speculate that unidentified interaction sites may be critical for Bax activation, or mechanisms other than protein-protein interactions need to be considered to delineate how Bax is activated during apoptosis.

\section{Experimental Procedures}

Cell culture. Human colorectal cancer cell line HCT116 was obtained from the American Type Culture Collection (ATCC; Manassas, VA, USA). BAX-KO HCT116 cells were previously described, ${ }^{21}$ and were from Dr. Bert Vogelstein (Johns Hopkins University). All cell lines were cultured in McCoy's 5 A modified medium (Invitrogen, Carlsbad, CA, USA) supplemented with 10\% defined fetal bovine serum (HyClone, Logan, UT, USA), $100 \mathrm{units} / \mathrm{ml}$ penicillin and $100 \mu \mathrm{g} / \mathrm{ml}$ streptomycin (Invitrogen). Cells were maintained in a $37^{\circ} \mathrm{C}$ incubator at $5 \%$ $\mathrm{CO}_{2}$. For apoptosis induction, cells plated in 12-well plates at $20-30 \%$ density were treated with sulindac, indomethacin and TRAIL diluted with cell culture media, or infected with a PUMA-expressing adenovirus. ${ }^{32}$

KI of WT and mutant Bax. Vectors for knocking-in WT and mutant Bax were constructed using the pUSER-rAAV (recombinant adeno-associated virus) System. ${ }^{37}$ Briefly, two homologous arms of $\sim 1 \mathrm{~kb}$ each flanking the first intron of $B A X$ were inserted between 2 USER sites in the AAV shuttle vector pTK-NeoUSER (Figure 1a). The coding sequences for K21E, D33A, D68R and L70A/D71A mutants were introduced into the right arm using the QuickChange XL SiteDirected Mutagenesis Kit (Agilent Technologies, Santa Clara, CA, USA). For gene targeting, BAX-KO HCT116 cells were infected with the targeting rAAV and selected by G418 (0.5 mg/ml; Mediatech, Manassas, VA, USA) for 3 weeks. G418resistant clones were pooled and screened by PCR for targeting events using the primer pairs listed in Supplementary Table S1. BAX-KO cells contain a KO allele, which lacks a part of exon 2 and entire exons 3 and 4 , and a null allele that is not expressed due to a frame-shift deletion in a G8 tract in exon $3 .{ }^{21}$ Targeting constructs were designed specifically to the $B A X$ allele with the frame-shift deletion. To $\mathrm{KI}$ the S184V mutant, a different targeting rAAV was constructed by inserting two homologous arms flanking intron 5 of $B A X$ between 2 USER sites (Figure 1b), and used to infect the WT BAX-KI cells (WT-KI), followed by G418 selection and PCR screening of targeting events using the primers listed in Supplementary Table S2. After one round of gene targeting, Neo was excised by Cre adenovirus infection. ${ }^{38}$ All targeting events were verified by sequencing of genomic DNA and CDNA isolated from the $\mathrm{KI}$ cells, and by western blot analysis of Bax expression.

Western blotting and antibodies. Western blotting was performed as previously described. ${ }^{20}$ Antibodies included those against Bad, Bid, caspase 9 (Cell Signaling, Beverly, MA, USA), Bax (N20; Santa Cruz Biotechnology, Santa Cruz, CA, USA), GFP, hemaglutinin (HA), cytochrome $c$, $\alpha$-tubulin (BD Biosciences, San Jose, CA, USA), V5, cytochrome oxidase subunit IV (Invitrogen), Flag (Sigma, St Louis, MO, USA), Bim, $\beta$-actin (EMD Biosciences, Philadelphia, PA, USA), Bak (Millipore, Bellerica, MA, USA), and PUMA. ${ }^{39}$

Transfection and expression constructs. Cells were transfected using Lipofectamine 2000 (Invitrogen) according to the manufacturer's instructions. Expression constructs of HA-tagged PUMA, V5-tagged Bcl- $\mathrm{X}_{\mathrm{L}}$ and GFP-tagged Bax were previously described. ${ }^{20}$ Expression constructs of $\mathrm{HA}$-tagged Bim, V5tagged $\mathrm{Bcl}-2, \mathrm{Bcl}-\mathrm{w}$ and tBid and Flag-tagged Mcl-1 are described elsewhere. ${ }^{40}$ Expression constructs of Bax mutants were generated from the GFP-Bax expression construct using the QuickChange XL Site-Directed Mutagenesis Kit (Agilent Technologies).

Immunoprecipitation. Twenty-four hours after transfection, cells were harvested and resuspended in $1 \mathrm{ml}$ of EBC buffer $(50 \mathrm{~mm}$ Tris- $\mathrm{HCl}, \mathrm{pH} 7.5$, $100 \mathrm{~mm} \mathrm{NaCl}, 0.5 \%$ NP-40) supplemented with a protease inhibitor cocktail (Roche Applied Sciences, Indianapolis, IN, USA). In some cases, $0.5 \%$ of CHAPS, instead of NP-40, was used as detergent for cell lysis. Cells were disrupted by sonication and then spun at $10000 \times g$ for $10 \mathrm{~min}$ to collect cell lystate. For IP, $1-2 \mu \mathrm{g}$ of IP antibodies were mixed with protein $\mathrm{G} / \mathrm{A}$-agarose beads (Invitrogen) for $20 \mathrm{~min}$ at 
room temperature. The beads were washed twice with PBS containing $0.02 \%$ Tween 20 (pH 7.4), incubated with cell lysates on a rocker for $6 \mathrm{~h}$ at room temperature, and then washed thrice with PBS ( $\mathrm{pH} 7.4)$. Beads were then boiled in $2 \times$ Laemmli buffer and subjected to SDS-polyacrylamide gel electrophoresis and western blot analysis.

Detection of Bax conformational change. Cells were lysed in CHAPS buffer $(150 \mathrm{~mm} \mathrm{NaCl}, 10 \mathrm{~mm}$ Hepes, pH 7.4, and 1\% CHAPS) containing protease inhibitor cocktail, incubated on ice for $20 \mathrm{~min}$, and then centrifuged at $15000 \times \mathrm{g}$ for $15 \mathrm{~min}$ to precipitate nuclei and cell debris. Cell lysates were then incubated with $2 \mu \mathrm{g}$ of anti-Bax 6A7 monoclonal antibody (Sigma) at $4{ }^{\circ} \mathrm{C}$ for $1 \mathrm{~h}$. After addition of $30 \mu \mathrm{l}$ of EZview Red protein $\mathrm{G}$ affinity gel (Sigma), samples were incubated at $4{ }^{\circ} \mathrm{C}$ overnight. Immunoprecipitates were collected by a brief spin, washed thrice with $1 \mathrm{ml}$ CHAPS buffer, solubilized with $1 \times$ Laemmli buffer, and analyzed by SDS-polyacrylamide gel electrophoresis and western blotting

Analysis of apoptosis. After treatment, cells were collected at different time points. Apoptosis was analyzed by nuclear staining with Hoechst 33258 (Invitrogen), as previously described. ${ }^{41}$ Activation of caspase 9 was analyzed by western blotting. For annexin V staining, cells were stained by Alexa-488conjugated annexin $\mathrm{V}$ and propidium iodide, and then analyzed by flow cytometry as previously described. ${ }^{42}$ For detection of mitochondrial membrane potential change, cells were stained by MitoTracker Red CMXRos (Invitrogen) for $15 \mathrm{~min}$ at room temperature, and then analyzed by flow cytometry.

Localization of WT and mutant Bax proteins. To analyze localization of WT and mutant Bax, BAX-KO cells and MEF cells were seeded on glass chamber slides (Thermo Fisher, Waltham, MA, USA) and transfected with GFPtagged WT or mutant Bax. After $24 \mathrm{~h}$, cells were incubated with $100 \mathrm{nM}$ of MitoTracker Red (CmxRos; Invitrogen) at $37^{\circ} \mathrm{C}$ for $20 \mathrm{~min}$ to label the mitochondria. Mounted slides were subjected to confocal fluorescence microscopy using a Zeiss LSM Pascal 5 and the Plan-Apochromat 63_1.40 Oil DIC objective lenses. Images were acquired using the Zeiss LSM Image Browser software (Carl Zeiss, Jena, Germany).

Analysis of cytochrome $c$ release and Bax multimerization. Cytoplasmic and mitochondrial fractions were separated by Mitochondrial Fractionation Kit (Active Motif, Carlsbad, CA, USA) according to the manufacturer's instructions. Cytochrome $c$ in both cytoplasmic and mitochondrial fractions was detected by western blotting. To detect Bax multimerization, the purified mitochondrial fractions were cross-linked with $1 \mathrm{~mm}$ of dithiobis (succinimidyl) propionate (DSP) (Thermo Fisher) as described, ${ }^{32}$ followed by western blotting under non-denaturing conditions.

Statistical analysis. Statistical analysis was conducted using GraphPad Prism IV software, GraphPad Software, La Jolla, CA, USA. P-values were calculated by Student's $t$-test. Differences were considered significant if the probability of the difference occurring by chance was less than 5 in $100(P<0.05)$.

\section{Conflict of Interest}

The authors declare no conflict of interest.

Acknowledgements. We thank Dr. Monica E Buchanan and other lab members for critical reading. This work is supported by China Scholarship Council (RP), the Ministry of Science and Technology of China (2009CB918903), NIH grants CA106348 and CA121105, American Cancer Society grant RSG-07-156-01-CNE, the Career Investigator Award from the American Lung Association/CHEST Foundation (LZ) and NIH grant CA129829 and American Cancer Society grant RSG-10-124-10CCE (JY). LZ is a scholar of the V Foundation for Cancer Research.

1. Danial NN, Korsmeyer SJ. Cell death. Critical control points. Cell 2004; 116: 205-219.

2. Wang X. The expanding role of mitochondria in apoptosis. Genes Dev 2001; 15 2922-2933.

3. Adams JM, Cory S. The Bcl-2 apoptotic switch in cancer development and therapy. Oncogene 2007; 26: 1324-1337

4. Youle RJ, Strasser A. The BCL-2 protein family: opposing activities that mediate cell death Nat Rev Mol Cell Biol 2008; 9: 47-59.
5. Green DR, Kroemer G. The pathophysiology of mitochondrial cell death. Science 2004; 305: 626-629

6. Wang C, Youle RJ. The role of mitochondria in apoptosis*. Annu Rev Genet 2009; 43 : $95-118$

7. Hsu YT, Wolter KG, Youle RJ. Cytosol-to-membrane redistribution of Bax and $\mathrm{Bcl}-\mathrm{X}(\mathrm{L})$ during apoptosis. Proc Natl Acad Sci USA 1997; 94: 3668-3672.

8. Gross A, Jockel J, Wei MC, Korsmeyer SJ. Enforced dimerization of BAX results in its translocation, mitochondrial dysfunction and apoptosis. Embo J 1998; 17: 3878-3885.

9. Llambi F, Moldoveanu T, Tait SW, Bouchier-Hayes L, Temirov J, McCormick LL et al. A unified model of mammalian BCL-2 protein family interactions at the mitochondria. $\mathrm{Mol}$ Cell 2011; 44: 517-531.

10. Giam $M$, Huang DC, Bouillet $\mathrm{P}$. BH3-only proteins and their roles in programmed cell death. Oncogene 2008; 27(Suppl 1): S128-S136.

11. Willis SN, Fletcher Jl, Kaufmann T, van Delft MF, Chen L, Czabotar PE et al. Apoptosis initiated when $\mathrm{BH} 3$ ligands engage multiple Bcl-2 homologs, not Bax or Bak. Science 2007; 315: 856-859.

12. Kim H, Tu HC, Ren D, Takeuchi O, Jeffers JR, Zambetti GP et al. Stepwise activation of BAX and BAK by tBID, BIM, and PUMA initiates mitochondrial apoptosis. Mol Cell 2009; 36: $487-499$

13. Gallenne T, Gautier F, Oliver L, Hervouet E, Noel B, Hickman JA et al. Bax activation by the $\mathrm{BH} 3-$ only protein Puma promotes cell dependence on antiapoptotic $\mathrm{Bcl}-2$ family members. J Cell Biol 2009; 185: 279-290.

14. Marani M, Tenev T, Hancock D, Downward J, Lemoine NR. Identification of novel isoforms of the $\mathrm{BH} 3$ domain protein Bim which directly activate Bax to trigger apoptosis. Mol Cell Biol 2002; 22: 3577-3589

15. George NM, Evans JJ, Luo X. A three-helix homo-oligomerization domain containing BH3 and $\mathrm{BH} 1$ is responsible for the apoptotic activity of Bax. Genes Dev 2007; 21: 1937-1948.

16. Fletcher Jl, Meusburger S, Hawkins CJ, Riglar DT, Lee EF, Fairlie WD et al. Apoptosis is triggered when prosurvival Bcl-2 proteins cannot restrain Bax. Proc Natl Acad Sci USA 2008; 105: 18081-18087.

17. Kim H, Rafiuddin-Shah M, Tu HC, Jeffers JR, Zambetti GP, Hsieh JJ et al. Hierarchical regulation of mitochondrion-dependent apoptosis by BCL-2 subfamilies. Nat Cell Biol 2006; 8: $1348-1358$

18. Cartron PF, Gallenne T, Bougras G, Gautier F, Manero F, Vusio P et al. The first alpha helix of Bax plays a necessary role in its ligand-induced activation by the $\mathrm{BH} 3-$ only proteins Bid and PUMA. Mol Cell 2004; 16: 807-818.

19. Gavathiotis E, Suzuki M, Davis ML, Pitter K, Bird GH, Katz SG et al. BAX activation is initiated at a novel interaction site. Nature 2008; 455: 1076-1081.

20. Ming L, Wang $P$, Bank A, Yu J, Zhang L. PUMA dissociates Bax and BCL-XL to induce apoptosis in colon cancer cells. J Biol Chem 2006; 281: 16034-16042.

21. Zhang L, Yu J, Park BH, Kinzler KW, Vogelstein B. Role of BAX in the apoptotic response to anticancer agents. Science 2000; 290: 989-992.

22. Burns TF, El-Deiry WS. Identification of inhibitors of TRAIL-induced death (ITIDs) in the TRAIL-sensitive colon carcinoma cell line SW480 using a genetic approach. J Biol Chem 2001; 276: 37879-37886.

23. LeBlanc H, Lawrence D, Varfolomeev E, Totpal K, Morlan J, Schow $\mathrm{P}$ et al. Tumor-cell resistance to death receptor-induced apoptosis through mutational inactivation of the proapoptotic Bcl-2 homolog Bax. Nat Med 2002; 8: 274-281.

24. Qiu W, Wang X, Leibowitz B, Liu H, Barker N, Okada H et al. Chemoprevention by nonsteroidal anti-inflammatory drugs eliminates oncogenic intestinal stem cells via SMACdependent apoptosis. Proc Natl Acad Sci USA 2010; 107: 20027-20032.

25. Chen K, Tu Y, Zhang Y, Blair HC, Zhang L, Wu C. PINCH-1 regulates the ERK-Bim pathway and contributes to apoptosis resistance in cancer cells. J Biol Chem 2008; 283: 2508-2517.

26. Bank $A$, Yu J, Zhang $L$. NSAIDs downregulate $B c l-X(L)$ and dissociate $B A X$ and $B c l-X(L)$ to induce apoptosis in colon cancer cells. Nutr Cancer 2008; 60(Suppl 1): 98-103.

27. Nechushtan A, Smith CL, Hsu YT, Youle RJ. Conformation of the Bax C-terminus regulates subcellular location and cell death. Embo J 1999; 18: 2330-2341.

28. Ren D, Tu HC, Kim H, Wang GX, Bean GR, Takeuchi $O$ et al. BID, BIM, and PUMA are essential for activation of the BAX-and BAK-dependent cell death program. Science 2010; 330: $1390-1393$

29. Leber B, Lin J, Andrews DW. Still embedded together binding to membranes regulates Bcl-2 protein interactions. Oncogene 2010; 29: 5221-5230.

30. Dewson G, Kratina T, Sim HW, Puthalakath H, Adams JM, Colman PM et al. To trigger apoptosis, Bak exposes its $\mathrm{BH} 3$ domain and homodimerizes via $\mathrm{BH} 3$ :groove interactions. Mol Cell 2008; 30: 369-380.

31. Dewson G, Kluck RM. Mechanisms by which Bak and Bax permeabilise mitochondria during apoptosis. J Cell Sci 2009; 122(Pt 16): 2801-2808.

32. Yu J, Wang Z, Kinzler KW, Vogelstein B, Zhang L. PUMA mediates the apoptotic response to p53 in colorectal cancer cells. Proc Natl Acad Sci USA 2003; 100 1931-1936.

33. Lindsten T, Ross AJ, King A, Zong WX, Rathmell JC, Shiels HA et al. The combined functions of proapoptotic Bcl-2 family members bak and bax are essential for normal development of multiple tissues. Mol Cell 2000; 6: 1389-1399.

34. Wang C, Youle RJ. Predominant requirement of Bax for apoptosis in HCT116 cells is determined by Mcl-1's inhibitory effect on Bak. Oncogene 2012; 31: 3177-3189. 
35. Zhou H, Hou Q, Hansen JL, Hsu YT. Complete activation of Bax by a single site mutation. Oncogene 2007; 26: 7092-7102.

36. Ravi R, Bedi GC, Engstrom LW, Zeng Q, Mookerjee B, Gelinas C et al. Regulation of death receptor expression and TRAIL/Apo2L-induced apoptosis by NF-kappaB. Nat Cell Biol 2001; 3: 409-416.

37. Zhang X, Guo C, Chen Y, Shulha HP, Schnetz MP, LaFramboise T et al. Epitope tagging of endogenous proteins for genome-wide ChIP-chip studies. Nat Methods 2008; 5: 163-165.

38. Wang P, Yu J, Zhang L. The nuclear function of p53 is required for PUMA-mediated apoptosis induced by DNA damage. Proc Natl Acad Sci USA 2007; 104: 4054-4059.
39. Dudgeon C, Peng R, Wang P, Sebastiani A, Yu J, Zhang L. Inhibiting oncogenic signaling by sorafenib activates PUMA via GSK3beta and NF-kappaB to suppress tumor cell growth. Oncogene 2012; 31: 4848-4858.

40. Ming L, Yanamala N, Li M, Moss C, Klein-Seetharaman J, Yu J et al. In preparation.

41. Kohli M, Yu J, Seaman C, Bardelli A, Kinzler KW, Vogelstein B et al. SMAC/Diablodependent apoptosis induced by nonsteroidal antiinflammatory drugs (NSAIDs) in colon cancer cells. Proc Natl Acad Sci USA 2004; 101: 16897-16902.

42. Li H, Wang P, Sun Q, Ding WX, Yin XM, Sobol RW et al. Following cytochrome c release, autophagy is inhibited during chemotherapy-induced apoptosis by caspase 8-mediated cleavage of Beclin 1. Cancer Res 2011; 71: 3625-3634.

Supplementary Information accompanies the paper on Cell Death and Differentiation website (http://www.nature.com/cdd) 